ORIGINAL ARTICLE

\title{
Effects of acrylic removable partial dentures on periodontal health of abutment teeth.
}

\author{
Samia Shafiq ${ }^{1}$, Nazia Yazdanie ${ }^{2}$
}

Article Citation: Shafiq S, Yazdanie N. Effects of acrylic removable partial dentures on periodontal health of abutment teeth. Professional Med J 2022; 29(3):382-388. https://doi.org/10.29309/TPMJ/2022.29.03.6109

\begin{abstract}
Objective: To assess the outcomes in patients wearing particularly designed acrylic removable partial dentures at different time intervals. Study Design: Descriptive Case Series Study. Setting: Department of Prosthodontics, FMH College of Dentistry, Lahore. Period: October 2017 to April, 2018. Material \& Methods: Sixty five (65) abutments of acrylic removable partial denture wearers were included in the study for assessment of Mean Clinical Attachment Level $(\mathrm{CAL})$, Tooth Mobility (TM) and Mean Gingival Index (GI). These periodontal parameters were clinically assessed at the day of insertion, $30^{\text {th }}$ day and $60^{\text {th }}$ day of insertion. Mean Clinical Attachment Level (CAL) was measured by William's Probe. Tooth Mobility (TM) was assessed using Miller's Classification. Gingival health was evaluated using the Gingival Index (GI) of Loe and Silness. Mean and standard deviation were calculated for patient's age and all the periodontal scores of abutment teeth. Data was stratified for age and gender to identify the effect modifiers. Pearson chi-square test was used for Mean Gingival Index, and Mean Tooth Mobility. Post-stratification student t-test for Mean Clinical Attachment Level was used to compare the results with $p \leq 0.05$ considered as significant. Results: Sstatistically insignificant results for all the periodontal parameters, i.e. the Mean Gingival Index (GI), Tooth Mobility (TM) and Mean Clinical Attachment Loss (CAL) were observed, age being not influencing the periodontal health of abutments. The only statistically significant $(p=0.01)$ result was observed for the Tooth Mobility (TM) in gender categories at the day of insertion and the $30^{\text {th }}$ day of insertion. Conclusion: All the periodontal parameters, except tooth mobility (TM) assessed in the study, were not affected by the acrylic removable partial denture wearing.
\end{abstract}

Key words: Abutment Teeth, Acrylic Removable Partial Dentures, Periodontal Health.

\section{INTRODUCTION}

A removable partial denture is a prosthetic restoration that replaces the missing teeth in a partially dentate arch. It derives its support from the underlying tissues and the abutment teeth. ${ }^{1}$ Impaired oral functions (esthetics, phonetics and mastication) are the main indication for removable partial dentures. Thus, the main goal of prosthodontic treatment is to improve these functions for the individual ${ }^{2}$ and to preserve the remaining teeth. ${ }^{3}$

Clinicians can offer a variety of treatment regimens to the partially dentate patients and majority of the prescriptions consist of Removable Partial Dentures (RPDs). ${ }^{4}$ The dentures can be made with a variety of materials, but acrylic resin or a combination of cast metal alloy $(\mathrm{Co} / \mathrm{Cr})$ framework and acrylic resin are the most frequent materials used for this purpose. Removable partial denture (RPD) is an adequate form of the prosthodontic treatment for partially dentate patients as these dentures represent an acceptable and economical treatment modality. ${ }^{5}$

However, RPDs are accompanied by a high biological price with increased risk of caries and periodontal diseases reported in denture wearers. ${ }^{4}$ The most common documented adverse effects of RPDs include; gingivitis, periodontitis and mobility of abutment teeth. These detrimental changes occur due to poor oral hygiene, increased plaque and calculus accumulation. ${ }^{5}$ The RPD in the mouth has the
1. BDS, Resident Prosthodontics, FMH College of Dentistry, Lahore, Pakistan.

2. PhD, MSc, FCPS, FDS RCPS, BDS, Pro -Vice Chancellor, Nur International University, Lahore, Pakistan.

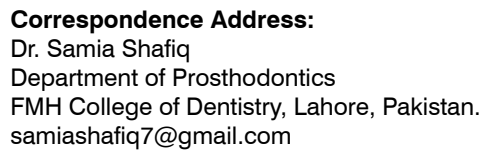

Correspondence Address:

Dr. Samia Shafiq

Department of Prosthodontics

FMH College of Dentistry, Lahore, Pakistan. samiashafiq7@gmail.com

Article received on: 
potential for increased plaque p-6 $^{5}$ and biofilm formation ${ }^{1}$ on the abutment teeth receiving clasps or attachments. ${ }^{5}$ Periodontal structure can be protected from damage by periodic professional dental checkups recalls, adequate oral hygiene measures $^{6-7}$ and simplicity in denture design. ${ }^{8}$ Only a few studies have demonstrated the adverse effects of acrylic partial dentures on the health of oral soft tissues..$^{8-12}$

Acrylic removable partial dentures can be fabricated according to different design concepts but the previous studies ${ }^{8-12}$ had a gap in defining the design specifications of the acrylic RPDs observed, so it is difficult to generalize the results for their clinical application. Therefore, the effects of one particular design of acrylic removable partial dentures on periodontal health of abutment teeth are being assessed in partially dentate patients visiting a tertiary care hospital in Lahore.

\section{MATERIAL \& METHODS}

An Institutional Review Board Approval (FMK-032020-IRB-756-M) was secured and the study was conducted in the Department of Prosthodontics, FMH College of Dentistry, Lahore from October 2017 to April 2018. It was a Descriptive Case Series Study. The study included sixty five (65) abutment teeth. Non-probability consecutive sampling technique was adopted for data collection. Patients of both genders and age group ranging from 40-60 years were included in the study. The denture design comprised of cast metal alloy $(\mathrm{Co} / \mathrm{Cr})$ clasp assembly for support and retention. Also, full coverage acrylic lingual plate and palatal plate/ palatal strap major connectors were fabricated for mandibular and maxillary arches, respectively. Only the first time denture wearing patients facilitated with these particularly designed heat cured acrylic removable partial dentures were considered in the study.

On the contrary, patients diagnosed with generalized Gingivitis or Periodontitis, psychiatric conditions, systemic diseases (Sojgren Syndrome, diabetes, and hypertension), alcohol or drug intoxication and smokers were excluded. Also, patients with poor oral and denture hygiene maintenance and daily denture use of more than 16 hours after denture insertion were considered as dropouts of the study.

Each of the eligible patients was clinically examined by the operator at the day of insertion, $30^{\text {th }}$ and $60^{\text {th }}$ day of insertion.

Following periodontal parameters were recorded for each tooth:

1. Mean Clinical Attachment Level (CAL) was measured by William's Probe and read to the nearest millimeter $(\mathrm{mm})$ at four areas (i.e. mesiobuccal, distobuccal, mesiolingual, and distolingual) of each abutment tooth. The mean value of all the four areas was considered for statistical evaluation.

2. The tooth mobility was clinically assessed by using Miller's Classification. ${ }^{13}$

3. The gingival health condition was assessed by using the Gingival Index (Gl) of Loe and Silness. ${ }^{14}$

The collected data was entered and analyzed in SPSS (version 20.0 for windows). Mean and standard deviation were calculated for patient's age and all the periodontal scores of abutment teeth (i.e. Mean GI, Mean TM and Mean CAL). Frequency and percentages were calculated for qualitative data i.e. gender. Data was stratified for age and gender to identify the effect modifiers. Pearson chi-square test was used for Mean GI, and Mean TM. Post-stratification student t-test was used to compare the results with $p \leq 0.05$ considered as significant.

\section{RESULTS}

A total of sixty five (65) abutments of patients (both genders) were enrolled for the assessment of periodontal parameters, out of which $52.3 \%$ were male patients and $47.7 \%$ were female patients with mean age of $49.22 \pm 6.64$ years. The assessment was done at the day of insertion, $30^{\text {th }}$ and $60^{\text {th }}$ day of insertion.

The overall effects of acrylic removable partial dentures on Mean Gl, Mean TM and Mean CAL in age category have been illustrated in Tables-I,II and III, respectively. Likewise, the effects of acrylic 
removable partial dentures on Mean GI, Mean TM and Mean CAL in gender category have been presented in Tables-IV,V and VI, respectively.

Statistically insignificant findings were observed for Mean Gl in age category, indicating that age had no influence on the $\mathrm{Gl}$ at each follow-up ( $p$-values of 0.28 and 0.35 respectively) (Table-I). Likewise, $\mathrm{Gl}$ at $30^{\text {th }}$ day and $60^{\text {th }}$ day of insertion indicated that gender had no influence on the Gl as $p$-value proved to be statistically insignificant for each follow-up with $p$-values of 0.28 , and 0.35 respectively (Table-IV).

Similar statistically insignificant findings were observed for Mean TM at $30^{\text {th }}$ and $60^{\text {th }}$ day of insertion with p-values of 0.45 and 0.48 respectively, indicating that age was not an effect modifier on the TM at each follow-up (Table-II). On the contrary, Mean Tooth Mobility (TM) at $30^{\text {th }}$ day of insertion depicted that gender had positive impact on the tooth mobility with $p$-value $=0.01$ (Table-IV).

Mean CAL was found to be insignificant in age category at $30^{\text {th }}$ and $60^{\text {th }}$ days of insertion, $p$-value being 0.06 and 0.40 respectively (Table-III). The same statistically insignificant results for Mean CAL were observed at all the follow-ups in gender category, $p$-values being $0.97,0.15$ and 0.70 respectively. (Table-VI).

\begin{tabular}{|c|c|c|c|c|c|c|}
\hline & $\begin{array}{c}\text { Age } \\
\text { Categories }\end{array}$ & Normal & Mild & Moderate & Severe & $\begin{array}{c}\text { P-Value } \\
\text { (Chi-square) }\end{array}$ \\
\hline \multirow{2}{*}{$\begin{array}{l}\text { Gingival Index at the Day } \\
\text { of Insertion }\end{array}$} & $40-50$ & 17 & 24 & $=$ & $=$ & \multirow{2}{*}{0.75} \\
\hline & $51-60$ & 9 & 15 & $=$ & $=$ & \\
\hline \multirow{2}{*}{$\begin{array}{l}\text { Gingival Index at } 30^{\text {th }} \\
\text { Day of Insertion }\end{array}$} & $40-50$ & 4 & 28 & 9 & $=$ & \multirow{2}{*}{0.28} \\
\hline & $51-60$ & 0 & 18 & 6 & $=$ & \\
\hline \multirow{2}{*}{$\begin{array}{l}\text { Gingival Index at } 60^{\text {th }} \\
\text { Day of Insertion }\end{array}$} & $40-50$ & 6 & 20 & 15 & 0 & \multirow{2}{*}{0.35} \\
\hline & $51-60$ & 2 & 9 & 12 & 1 & \\
\hline
\end{tabular}

Table-I. Mean Gingival Index at the Day of Insertion, $30^{\text {th }}$ Day and $60^{\text {th }}$ Day of Insertion in Age Categories.

\begin{tabular}{|c|c|c|c|c|c|}
\hline & $\begin{array}{c}\text { Age } \\
\text { Categories }\end{array}$ & $\begin{array}{l}\text { Normal; within } \\
\text { physiologic } \\
\text { limit }\end{array}$ & $\begin{array}{l}\text { Tooth Mobility; } \\
\text { greater than } \\
\text { physiologic limit }\end{array}$ & $\begin{array}{l}\text { Tooth Mobility; } 1 \mathrm{~mm} \\
\text { or more in lateral } \\
\text { direction Only }\end{array}$ & $\begin{array}{c}\text { P-Value } \\
\text { (Chi-square) }\end{array}$ \\
\hline \multirow{2}{*}{$\begin{array}{l}\text { Tooth Mobility at the Day } \\
\text { of Insertion }\end{array}$} & $40-50$ & 15 & 26 & $=$ & \multirow{2}{*}{0.29} \\
\hline & $51-60$ & 12 & 12 & $=$ & \\
\hline \multirow{2}{*}{$\begin{array}{l}\text { Tooth Mobility at } 30^{\text {th }} \text { Day } \\
\text { of Insertion }\end{array}$} & $40-50$ & 4 & 29 & $=$ & \multirow{2}{*}{0.45} \\
\hline & $51-60$ & 2 & 20 & $=$ & \\
\hline \multirow{2}{*}{$\begin{array}{l}\text { Tooth Mobility at } 60^{\text {th }} \text { Day } \\
\text { of Insertion }\end{array}$} & $40-50$ & 9 & 24 & 8 & \multirow{2}{*}{0.48} \\
\hline & $51-60$ & 6 & 16 & 2 & \\
\hline
\end{tabular}

Table-II. Mean tooth mobility at the day of insertion, $30^{\text {th }}$ Day and $60^{\text {th }}$ Day of insertion in age categories.

\begin{tabular}{|c|c|c|c|c|c|}
\hline & Age Categories & $\mathbf{n}$ & Mean & SD & P-Value \\
\hline \multirow{2}{*}{$\begin{array}{l}\text { Mean Clinical Attachment Loss at the Day } \\
\text { of Insertion }\end{array}$} & $40-50$ & 41 & 1.55 & 0.60 & \multirow[b]{2}{*}{0.68} \\
\hline & $51-60$ & 24 & 1.60 & 0.34 & \\
\hline \multirow{2}{*}{$\begin{array}{l}\text { Mean Clinical Attachment Loss at } 30^{\text {th }} \text { Day } \\
\text { of Insertion }\end{array}$} & $40-50$ & 41 & 1.72 & 0.55 & \multirow[b]{2}{*}{0.06} \\
\hline & $51-60$ & 24 & 1.97 & 0.47 & \\
\hline \multirow{2}{*}{$\begin{array}{l}\text { Mean Clinical Attachment Loss at } 60^{\text {th }} \text { Day } \\
\text { of Insertion }\end{array}$} & $40-50$ & 41 & 1.71 & 0.47 & \multirow[t]{2}{*}{0.40} \\
\hline & $51-60$ & 24 & 1.81 & 0.39 & \\
\hline
\end{tabular}

Table-III. Mean clinical attachment level at the day of insertion, $30^{\text {th }}$ day and $60^{\text {th }}$ day of insertion in age categories. 


\begin{tabular}{|l|c|c|c|c|c|}
\hline & Gender & Normal & Mild & Moderate & $\begin{array}{c}\text { P-Value } \\
\text { (chi- square) }\end{array}$ \\
\hline \multirow{2}{*}{$\begin{array}{l}\text { Gingival Index at the Day of } \\
\text { Insertion }\end{array}$} & Male & 10 & 24 & $=$ & $=$ \\
\hline \multirow{2}{*}{$\begin{array}{l}\text { Gingival Index at 30 } \\
\text { Insertion }\end{array}$} & Female & 16 & 15 & $=$ & $=$ \\
\hline \multirow{2}{*}{$\begin{array}{l}\text { Gingival Index at 30 } \\
\text { Insertion }\end{array}$} & Male & 1 & 25 & 8 & $=$ \\
\cline { 2 - 6 } & Female & 3 & 21 & 7 & $=$ \\
\hline
\end{tabular}

Table-IV. Mean gingival index at the day of insertion, $30^{\text {th }}$ day and $60^{\text {th }}$ day of insertion in gender categories.

\begin{tabular}{|c|c|c|c|c|c|}
\hline & Gender & $\begin{array}{c}\text { Normal; } \\
\text { Within } \\
\text { physiologic limit }\end{array}$ & $\begin{array}{c}\text { Tooth Mobility; } \\
\text { greater than } \\
\text { physiologic limit }\end{array}$ & $\begin{array}{l}\text { Tooth Mobility; 1mm } \\
\text { or more in lateral } \\
\text { direction Only }\end{array}$ & $\begin{array}{c}\text { P-Value } \\
\text { (chi- square) }\end{array}$ \\
\hline $\begin{array}{l}\text { Tooth Mobility at the } \\
\text { Day of Insertion }\end{array}$ & Female & 18 & 13 & $=$ & 0.01 \\
\hline $\begin{array}{l}\text { Tooth Mobility at } 30^{\text {th }} \\
\text { Day of Insertion }\end{array}$ & Male & 1 & 24 & 9 & 0.01 \\
\hline \multirow{2}{*}{$\begin{array}{l}\text { Tooth Mobility at } 60^{\text {th }} \\
\text { Day of Insertion }\end{array}$} & Male & 4 & 24 & 6 & \multirow{2}{*}{0.07} \\
\hline & Female & 11 & 16 & 4 & \\
\hline
\end{tabular}

Table-V. Mean tooth mobility at the day of insertion, $30^{\text {th }}$ day and $60^{\text {th }}$ day of insertion in gender categories.

\begin{tabular}{|l|l|l|l|l|}
\hline & Gender & $\mathbf{n}$ & Mean & SD \\
\hline $\begin{array}{l}\text { Mean Clinical Attachment Loss at the Day of } \\
\text { Insertion }\end{array}$ & Male & 34 & 1.57 & 0.38 \\
\cline { 2 - 5 } & Female & 31 & 1.57 & 0.65 \\
\hline $\begin{array}{l}\text { Mean Clinical Attachment Loss at 30 th Day of } \\
\text { Insertion }\end{array}$ & Male & 34 & 1.90 & 0.50 \\
\hline & Female & 31 & 1.71 & 0.56 \\
\hline $\begin{array}{l}\text { Mean Clinical Attachment Loss at 60 th Day of } \\
\text { Insertion }\end{array}$ & Male & 34 & 1.77 & 0.42 \\
\cline { 2 - 5 } & Female & 31 & 1.72 & 0.48 \\
\hline
\end{tabular}

Table-VI. Mean clinical attachment loss at the day of insertion, $30^{\text {th }}$ day and $60^{\text {th }}$ day of insertion in gender categories.

\section{DISCUSSION}

As in the loss of any body part, tooth loss can result in compromised function as well as loss of self-esteem and feeling of being aged. Once teeth are lost, the restoration of function and aesthetics, without causing additional complications and further tooth loss poses a challenge to the prosthodontists. ${ }^{15}$

Removable dentures are particularly frequent among older people in the industrialized world. ${ }^{16}$ Some countries report that one-third to half of the older people wear full dentures while up to threequarters wear removable complete and/or partial dentures. ${ }^{17-18}$ According to the American College of Prosthodontics, it is estimated that over the next 15 years, approximately 200 million people will be using dentures of some kind. ${ }^{19-20}$ A major public health challenge is to plan oral healthcare for this group of patients in whom avoidance of further tooth loss is of particular importance. ${ }^{21}$ Removable partial dentures are one of the most widely accepted means of replacement of lost teeth and associated soft tissues. These prostheses are generally anchored by means of clasps/retainers to hold the denture in the designated place. The introduction of partial dentures in the mouth has the potential for altering the oral environment and causing further damage, especially to the abutment teeth, to which the clasps are anchored. ${ }^{15,22}$

This study assessed the outcomes of the effects of acrylic removable partial dentures with cast 
clasp assemblies on the periodontal health of the abutment teeth. The previous clinical studies $^{8-12}$ related to the subject had a gap in defining the design specifications for the acrylic removable partial dentures, which may have resulted in unreliable findings. Therefore, it was observed most appropriate to first describe the prosthodontics design specifications for the prosthesis fabrication and then assess the effects of these standardized prostheses on the periodontal health of the abutment teeth on scheduled recall appointments.

In this study, patients of both genders with mean age of $49.22 \pm 6.64$ years participated and majority of them was males with a percentage of 52.3. The dropouts of the study based on the exclusion criteria were compensated by enrolling more patients to achieve the estimated sample size of 65 abutments.

Patient age and gender had no significant influence on the Mean GI and Mean CAL assessed at the day of insertion and the subsequent recall appointments, i.e. $30^{\text {th }}$ and $60^{\text {th }}$ day of insertion (Table-I,III, IV and VI). These findings are in agreement with the results of a number of previous studies. ${ }^{22-27}$ Wilding and Reddy ${ }^{28}$, also reported in a study that pocket depths in abutment teeth were not significantly greater than pocket depths of non-abutment teeth. These findings are attributed to the meticulous oral and denture hygiene maintenance protocols and regular attendance at recall visits. ${ }^{29-33}$

On the contrary, Mean TM was the only periodontal parameter that was significant in gender category at the day of insertion and the $30^{\text {th }}$ day of insertion (Table-V). This result has also been validated by Jorge et al, ${ }^{1}$ and Jayasinghe et al. ${ }^{34}$ One of the possible reason of this finding might be the clasping of the abutments, as it renders the abutments to bear additional forces that can cause tooth mobility. ${ }^{35-38}$ Tooth mobility might also be attributed to the fact that partial dentures in the mouth increase plaque formation ${ }^{39-45}$, particularly on tooth surfaces in contact with the partial denture. ${ }^{40}$
The Mean TM at the $60^{\text {th }}$ day of insertion proved to be statistically insignificant $(p$-value $=0.07$ ) (Table-II). This statistical finding points towards the significance of the recall visits. There seems to be a general agreement that the periodontal problems associated with the wearing of RPDs are related to the oral and denture hygiene practices and regular attendance at recall appointments by the denture wearers. Qudah and Nassrawin ${ }^{9}$, also support the significance of regular recall visits, as they play a vital role in re-evaluation the RPDs and execution of the necessary adjustments, rendering the applied loads in a favorable direction. In this way, the destruction of the periodontal apparatus is kept to a minimum and the integrity of the abutment can be preserved.

Simple, careful and logical partial denture design not only makes oral and denture hygiene practices easily for the denture wearers ${ }^{39}$, but also contribute to the general oral health of the patients.

\section{CONCLUSION}

This study concluded in statistically insignificant results for all the periodontal parameters, i.e. the Mean Gingival Index (GI), Tooth Mobility (TM) and Mean Clinical Attachment Loss (CAL), suggesting that age had no influence on the periodontal health of abutments. There was a statistically significant result observed only for the Tooth Mobility (TM) in gender categories at the day of insertion and the $30^{\text {th }}$ day of insertion.

These findings could be attributed to the patient education and counselling regarding maintenance of oral and denture hygiene, and periodic recall appointments.

Copyright@ 16 July, 2021.

\section{REFERENCES}

1. Jorge $J H$, Quishida CC, Vergani CE, Machado $A L$, Pavarina $A C$, and Giampaolo ET. Clinical evaluation of failures in removable partial dentures. $J$ Oral Sci 2012; 54 (4): 337-42.

2. O" Zhayat EB, and Gotfredsen K. Effect of treatment with fixed and removable dental prostheses. An oral health-related quality of life study. J Oral Rehabil 2012; 39: 28-36. 
3. Yamazaki S, Arakawa H, Maekawa K, Hara ES, Noda K, and Minakuchi $\mathrm{H}$ et al. Retrospective investigation of the remaining teeth status of patients with implantsupported fixed partial dentures in unilateral freeend edentulism. J Prosthod Res 2013; 57: 262-7.

4. Walter $\mathrm{MH}$, Weber $\mathrm{A}$, and Marré $\mathrm{B}$. Do removable dental prosthesis have an impact? J Dent Res 2010; 89: 818-22.

5. Dula LJ, Ahmedi EF, Lila-Krasniqi ZD, and Shala K. Clinical evaluation of removable partial dentures on the periodontal health of abutment teeth: A Retrospective Study. The Open Dent J 2015; 9:132-9.

6. Ezawi AAE, Gillam DG, Taylor PD. The Impact of Removable Partial Dentures on the Health of Oral Tissues: A Systematic Review. Int J Dent Oral Health 2017; 3(2): 1-8.

7. Rehmann $\mathrm{P}$, Orbach $\mathrm{K}$, Ferger $\mathrm{P}$, Wöstmann $\mathrm{B}$. Treatment outcomes with removable partial dentures: a retrospective analysis. Inte $\mathrm{J}$ Prosthod 2013; 26(2):147-50.

8. Mishra P, Agarwal S, Jain S, Devaraj CG, Yadav A, and Sharma S. Association between dental prosthesis and periodontal disease in a rural jaipur population. International J Med Sci Educ 2014; 1(3): 155-60.

9. Qudah SA, and Nassrawin N. Effect of removable partial denture on periodontal health. J Res Med Sci 2004; 11(2): 17-9.

10. Al Rawi AS. The Effect of Acrylic Removable Partial Dentures on Periodontal Health of Abutment and Non-Abutment Teeth. J Bagh Coll Dentistry 2010; 22(3): 80-2.

11. Dula LJ, Shala KS, Pustina-Krasniqi T, Bicaj T, and Ahmedi EF. The influence of removable partial dentures on the periodontal health of abutment and non-abutment teeth. Eur J Dent 2015; 9: 382-6.

12. Kazem NA, Abd ST, Abdulla WL, Dawood MAA, Admon $M$, and Sabah M. The Effect of Removable Partial Denture on Periodontal Health Status. GJBB 2017; 6 (3): 512-5.

13. Miller PD Jr. A classification of marginal tissue recession. Int J Perio Rest Dent 1985; 5(2): 9-13.

14. Löe $H$. and Silness, J. Periodontal disease in pregnancy. I. Prevalence and severity. Acta odont scand 1963: 21: 533-51.

15. Drake CW Beck JD. The oral status of elderly removable partial denture wearers. J Oral Rehabi 1993; 20(1): 53-60.
16. Commission of Oral Health, Research and Epidemiology Report of a Working Group. Oral health needs of the elderly - an international review. Int Dent J 1993; 43: 348-54.

17. Petersen PE, Kjoller M, Christensen LB, Krustrup U. Changing dentate status of adults, use of dental health services, and achievement of national dental health goals in Denmark by the Year 2000. J Public Health Dent 2004; 64: 127-35.

18. Randolph WM, Ostir GV, Markides KS. Prevalence of tooth loss and dental service use in older Mexican Americans. J Am Geriatr Soc 2001; 49: 585-9.

19. Williamson RA. Evidence based treatment for the edentulous patient's dentistry today 2010; 29(10): 140-5.

20. Younus Z, Maniya Z, Ahmed N, Faruqui S, Jouhar R, Maqsood A, and Allah Bukhsh $\mathrm{H}$. Periodontal health of natural abutments in removable partial denture wearers. PODJ 2017; 37(1): 175-8.

21. Preshaw PM, Walls AWG, Jakubovics NS, Moynihan PJ, Jepson NJA, and Loewy Z. Association of removable partial denture use with oral and systemic health. J Dent 2011; 39(11): 711-19.

22. Zlataric DK, Celebic A and Valentic-Peruzovic M. The effect of removable partial denture on periodontal health of the abutment and non-abutment teeth. J Periodontol 2002; 73: 137-44.

23. Mine K, Fueki K, and Igarashi Y. Microbiological risk for periodontitis of abutment teeth in patients with removable partial dentures. J Oral Rehabil 2009; 36: 696-702.

24. Bergman B, Hugoson A, and Olsson CO. Caries, periodontal and prosthetic findings in patients with removable partial dentures: A ten-year longitudinal study. J Prosthet Dent 1982; 48: 506-14.

25. Schwalm CA, Smith DE, Erickson JD. A clinical study of patients 1 to 2 years after placement of removable partial dentures. J Prosthet Dent 1977; 38: 380-91.

26. Muraki H, Wakabayashi N, Park I, and Ohyama T. Finite element contact stress analysis of the RPD abutment tooth and periodontal ligament. J Dent 2004; 32: 65965.

27. Piwowarczyk A, Köhler K, Bender R, Büchler A, Lauer H, and Ottl P. Prognosis for abutment teeth of removable dentures: A retrospective study. J Prosth Dent 2007; 16(5): 377-82. 
28. Nickenig A, Friedrich R, Kerschbaum T: Steg-Gelenk- vs. Teleskop-Prothese im reduzierten Restgebiss. [Dolder bar vs. telescopic copings for partial denture cases.] Dtsch Zahn"arztl Z 1993; 48: 566-69.

29. Wilding RJC, and Reddy J. Periodontal disease in partial denture wearers-a biological index. J Oral Rehabil, 1987; 14: 111-24.

30. Rodan R, Al-Jabrah O, and Ajarmah M. Adverse effects of removable partial dentures on periodontal status and oral health of partially edentulous patients. JRMS 2012; 19(3): 53-8.

31. Kern $M$, and Wagner $B$ : Periodontal findings in patients $\mathbf{1 0}$ years after insertion of removable partial dentures. J Oral Rehabil 2001; 28: 991-7.

32. Kapur KK, Deupree R, Dent RJ, et al: A randomized clinical trial of two basic removable partial denture designs. Part I: Comparisons of five-year success rates and periodontal health. J Prosthet Dent 1994; 72: $268-82$.

33. Mahmood WA, Salim SA, and Saharudin S. The status of the abutment teeth in distal extension removable partial dentures. Mala Dent J 2009; 30(1): 13-9.

34. Jayasinghe M, Tilakaratne A, Amarasena N, Mack F, and Anandamoorthy $\mathrm{T}$. Impact of marginal contact of removable acrylic partial. Inter $\mathrm{J}$ Res in Med and Health Sci 2013; 1(3): 1-11.

35. Winter A, Kochel J, Szép SG, Rijt DV, Brandt S, et al. (2019) Oral-health implications and maintenance needs of Removable Partial Dentures (RPDs) worn during pre-prosthetic treatment. J Dent Probl Solut 2019; 6(2): 061-4.
36. Feingold GM, Grant $A A$, Johnson $W$. The effect of partial denture design on abutment tooth and saddle movement. J Prosthet Dent 1980; 43: 15-21.

37. Feingold GM, Grant AA, Johnson W. The effect of variation of residual ridge angle on partial denture abutment tooth movement. J Oral Rehabil 1988; 15: 379-84.

38. Kratochvil FJ, Thompson WD, Caputo AA. Photoelastic analysis of stress patterns on teeth and bone with attachment retainers for removable partial dentures. J Prosthet Dent 1981; 46(1): 21-8.

39. Bergman B. Periodontal reactions related to removable partial dentures: A literature review. J Prosthet Dent 1987; 58(4): 454-7.

40. El Ghamrawy E. Quantitative changes in dental plaque formation related to removable partial dentures. $J$ Oral Rehabil 1976; 3(2): 115-20.

41. Brill N, Tryde G, Stoltze K, El Chamrawy EA. Ecologic changes in the oral cavity caused by removable partial dentures. J Prosthet Dent 1977; 38: 138-48.

42. Schwalm CA, Smith DE, Erickson JD. A clinical study of patients 1 to 2 years after placement of removable partial dentures. J Prosthet Dent 1977; 38: 380-91.

43. Addy M, Bates JF. Plaque accumulation following the wearing of different types of removable partial dentures. J Oral Rehabil 1979; 6: 111-7.

44. Bissada NF, Ibrahim SI, Barsoum WM. Gingival response to various types of removable partial dentures. J Periodontol 1974; 45: 651-59.

45. Berg E. Periodontal problems associated with use of distal extension removable partial dentures- A matter of construction? J Oral Rehabil 1985; 12: 36979.

\begin{tabular}{|c|c|c|c|}
\hline \multicolumn{4}{|c|}{ AUTHORSHIP AND CONTRIBUTION DECLARATION } \\
\hline No. & Author(s) Full Name & Contribution to the paper & Author(s) Signature \\
\hline 2 & $\begin{array}{l}\text { Samia Shafiq } \\
\text { Nazia Yazdanie }\end{array}$ & $\begin{array}{l}\text { Principal investigator, data } \\
\text { collection, literature search, } \\
\text { manuscript write-up. } \\
\text { Conceptualization of the stu- } \\
\text { dy, literature search, proof } \\
\text { reading and editing of the ma- } \\
\text { nuscript. }\end{array}$ & \\
\hline
\end{tabular}

